\title{
Geostatistical methods in evaluating spatial variability of groundwater quality in Al-Kharj Region, Saudi Arabia
}

\author{
Abdulrasoul M. Al-Omran ${ }^{1}$ - Anwar A. Aly ${ }^{1,3}$ - Mohammad I. Al-Wabel ${ }^{1}$ • \\ Mohammad S. Al-Shayaa ${ }^{2}$ Abdulazeam S. Sallam ${ }^{1} \cdot$ Mahmoud E. Nadeem ${ }^{1}$
}

Received: 9 June 2016/Accepted: 27 February 2017/Published online: 17 March 2017

(c) The Author(s) 2017. This article is an open access publication

\begin{abstract}
The analyses of 180 groundwater samples of AlKharj, Saudi Arabia, recorded that most groundwaters are unsuitable for drinking uses due to high salinity; however, they can be used for irrigation with some restriction. The electric conductivity of studied groundwater ranged between 1.05 and $10.15 \mathrm{dS} \mathrm{m}^{-1}$ with an average of $3.0 \mathrm{dS} \mathrm{m} \mathrm{m}^{-1}$. Nitrate was also found in high concentration in some groundwater. Piper diagrams revealed that the majority of water samples are magnesium-calcium/sulfate-chloride water type. The Gibbs's diagram revealed that the chemical weathering of rock-forming minerals and evaporation are influencing the groundwater chemistry. A kriging method was used for predicting spatial distribution of salinity $\left(\mathrm{EC} \mathrm{dS} \mathrm{m}{ }^{-1}\right)$ and $\mathrm{NO}_{3}{ }^{-}\left(\mathrm{mg} \mathrm{L}^{-1}\right)$ in Al-Kharj's groundwater using data of 180 different locations. After normalization of data, variogram was drawn, for selecting suitable model for fitness on experimental variogram, less residual sum of squares value was used. Then cross-validation and root mean square error were used to select the best method for interpolation. The kriging method was found suitable methods for groundwater interpolation and management using either GS+ or ArcGIS.
\end{abstract}

Abdulrasoul M. Al-Omran

rasoul@ksu.edu.sa

Anwar A. Aly

anwarsiwa@yahoo.com

1 Soil Science Department, College of Food and Agriculture Sciences, King Saud University, Riyadh, Saudi Arabia

2 Agricultural Extension and Rural Community Department, College of Food and Agriculture Sciences, King Saud University, Riyadh, Saudi Arabia

3 Soil and Water Science Department, Faculty of Agriculture, Alexandria University, Alexandria, Egypt
Keywords Spatial variability · GS+ · GIS · Hydrochemistry · Al-Kharj

\section{Introduction}

The increased exploitation of groundwater resources throughout the world especially in arid and semi-arid regions causes water quality deterioration and contamination (Aly et al. 2016). The Kingdom of Saudi Arabia (KSA), located in arid region, is currently suffering from limited renewable water resources (Aly et al. 2015a, b). The groundwater in KSA is considered the main source for irrigation. In last three decades, the groundwater is subjected to over exploitation reaching 17 billion $\mathrm{m}^{3}$ year $^{-1}$, and deterioration (Al-Omran et al. 2016). The increase demand of water for agricultural production has forced farmers to use unconventional water resources, i.e., treated municipal wastewater, to overcome their water need (AlOmran et al. 2004, 2016). The groundwater spatial variability in KSA requires further investigations to allow better management and conservation (Al-Omran et al. 2016). Al-Kharj, located east of Riyadh city in KSA, is an agroecosystem depend mostly on groundwater as a main source of drinking and irrigation purposes. Like other agroecosystem in KSA, the Al-Kharj agriculture areas have been deteriorated rapidly due to groundwater salinization (Aly et al. 2016). A good understanding of hydrochemical processes that govern groundwater quality is required for the sustainable management of the groundwater resources (Ledesma-Ruiz et al. 2015; El-Sayed et al. 2012). The estimation of soluble ions concentration in groundwater are much more time consuming. Therefore, it is necessary to find a simple approach can predict spatial distribution of

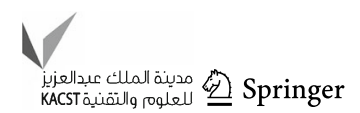


ions and contaminant throughout certain area. Classical statistics, which assumes completely independent measurements, was found unsuitable for capturing and describing spatial variability of soil and groundwater quality (Cemek et al. 2007). However, the geostatistics, a rapidly evolving branch of applied statistics and mathematics that offers a collection of tools, has been utilized extensively to illustrate the spatial variability in many fields. Several studies have been carried out to investigate the spatial variability of groundwater quality (Adhikary et al. 2012; Narany et al. 2015; Mahato et al. 2016; Singh et al. 2013). In recent year, the geostatistics and GIS techniques are very common practices to assess the groundwater, surface, and mine water quality and spatial variability (Khashei-Siuki and Sarbazi 2015; Tiwari et al. $2015,2016 a, b)$. The evaluating of spatial correlation of water quality variables is an important tool through the vairograms and kriging (Al-Omran et al. 2004). The geostatistics provides a set of statistical tools for incorporation the spatial and temporal coordinates of observations in data processing, allowing for description and modeling of spatial patterns, prediction at non sampled locations, and assessment of uncertainty attached to these predictions (Webster and Burgess 1980; Burgess et al. 1981). Geostatistical methods have become popular since 1980s; nevertheless, there is a shortage in information and knowledge concerning groundwater variability in KSA. The factorial kriging analysis is a variant of kriging that aims to estimate and map different sources of spatial variability determined from the experimental variograms (Goovaerts 1992, 1998). This multivariate geostatistical technique allows description of the spatial relationships as well as separating the sources of variation according to the spatial scales at which they operate (Imrie et al. 2008; McBratney and Webster 1983; Vaezil et al. 2010). Kumar and Remadevi (2006) have compared various models of variogram such as spherical, exponential, and Gaussian to identify the spatial variation of groundwater in Rajasthan, India. Marko et al. (2013) reported in their study of Wadi Usfan in the western region of Saudi Arabia that most of groundwater is not suitable for drinking purposes. Narany et al. (2015) reported that the groundwater quality of Amol-Bahol plain, Iran that maps generated by ordinary kriging of EC, SAR, $\mathrm{Na} \%$ indicated an increasing trend of concentration from western and southern areas to the east and north-east of the plain. The maps show groundwater quality gradually decreases from west and south sides to the north-eastern side. Nas (2009) reported on his study of 156 wells in Konya, Turkey with an area of $427.5 \mathrm{~km}^{2}$, that the ordinary kriging method used in groundwater parameters such as $\mathrm{EC}, \mathrm{Cl}^{-}, \mathrm{SO}_{4}{ }^{2-}$ showed higher concentration in northeast part of the study area. The main objective of this study was to investigate the spatial variability of 180 groundwaters in Al-Kharj, Saudi Arabia, by using geostatistical and GIS tools.

\section{Materials and methods}

\section{Study area}

Al-Kharj is a productive agro-ecosystem set in a desert depression and is irrigated by waters from natural springs and dug wells. The region produces date palms, other fruits (e.g., grapes), and vegetables (e.g., lettuce, carrots, tomatoes, cucumbers, and melons). Al-Kharj is a fragile dryland agroecosystem that has a low degree of resilience to external stresses and a low carrying capacity, i.e., a limited potential for the expansion of economic activities and population. The Al-Kharj governorate, located at $24^{\circ} 8^{\prime} 54^{\prime \prime} \mathrm{N}, 47^{\circ} 18^{\prime} 18^{\prime \prime} \mathrm{E}$, lies in a broad low area (wadi) in the center of the Kingdom of Saudi Arabia, $80 \mathrm{~km}$ from Riyadh, the capital of the kingdom. The term 'Al-Kharj' refers to a number of small towns. The two largest towns are Dilam and Asseeh, and the smaller towns in the region include Al-Hayathim, Yamamah, and Sulamiyya. In addition to these towns, the area has many smaller hamlets and villages. The climate of Al-Kharj is characterized by hot and dry summers with daytime temperatures range between 45 and $48{ }^{\circ} \mathrm{C}$; on the other hand, the winter daytime temperatures range between 20 and $25^{\circ} \mathrm{C}$; in contrast, the winter nights are cold with average temperature of -2 and $5{ }^{\circ} \mathrm{C}$. The average precipitation during winter is $51 \mathrm{~mm}$; however, no rainfall in summer is recorded (Aly et al. 2016).

\section{Hydrogeology}

The Primary origin aquifers in study area include the quaternary sands of the wadi systems which are quartzose sandstones, and conglomerates with primary porosity; and calcarenites, coquinites and oolitic limestone with secondary porosity (Vincent 2008). In Al-Kharj, the floods of many wadis (valleys), such as Wadi Hanifa, discharge water into Wadi Al-Kharj. The Al-Kharj ecosystem contains several springs, called Oyun or Asiah, and is considered to be one of the richest locations in the kingdom with respect to water resources; since ancient times (Vincent 2008).

\section{Sample collection and analyses}

In this study, groundwater samples were collected from 180 different locations in the Al-Kharj region of the KSA, in an attempt to capture the spatial variations in groundwater quality in the study area (Fig. 1). All samples were stored in the dark at room temperature. The samples were analyzed for $\mathrm{EC}, \mathrm{pH}, \mathrm{Ca}^{2+}, \mathrm{Mg}^{2+}, \mathrm{Na}^{+}, \mathrm{K}^{+}, \mathrm{HCO}_{3}{ }^{-}, \mathrm{Cl}^{-}$, 
Fig. 1 Location of the study area

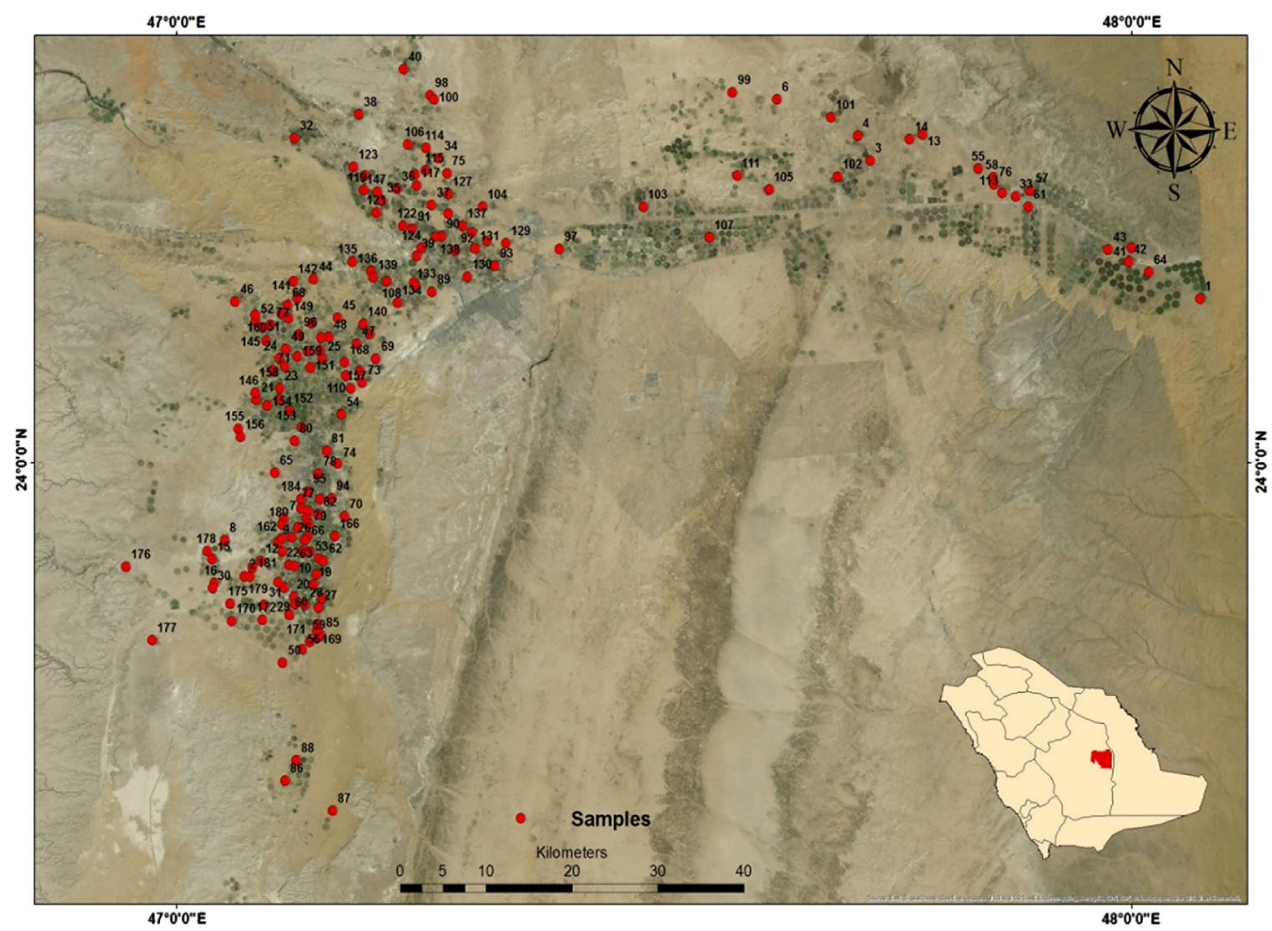

$\mathrm{SO}_{4}{ }^{2-}$, and $\mathrm{NO}_{3}{ }^{-}$. The EC was measured by using an EC meter in units of $\mathrm{dS} \mathrm{m}^{-1}$ at $25{ }^{\circ} \mathrm{C}$ (Test kit Model 1500_20 Cole and Parmer). The water reaction $(\mathrm{pH})$ was determined using a $\mathrm{pH}$ meter ( $\mathrm{pH}$ meter-CG 817). The soluble $\mathrm{Ca}^{2+}$ and $\mathrm{Mg}^{2+}$ were determined by versenate titration method (EDTA); however, the soluble $\mathrm{Na}^{+}$and $\mathrm{K}^{+}$concentrations were determined using flame photometer (Corning 400) (Matiti 2004). The $\mathrm{HCO}_{3}{ }^{-}$concentration was determined by titration with sulfuric acid $\left(\mathrm{H}_{2} \mathrm{SO}_{4}\right)$, whereas the $\mathrm{Cl}^{-}$ concentration was determined by titration with silver nitrate $\left(\mathrm{AgNO}_{3}\right)$ (Matiti 2004). The sulfate $\left(\mathrm{SO}_{4}{ }^{2-}\right)$ concentration was determined by the turbidity method (Tabatabai 1996), and the nitrate $\left(\mathrm{NO}_{3}{ }^{-}\right)$concentration was determined by the phenoldisulfonic acid method (APHA 1998). The boron (B) was determined by using azomethine-H method (Bingham 1982).

\section{Ion balance errors}

The correctness of the chemical analysis was verified by calculating ion balance errors; furthermore, standard solutions and blanks were commonly run to check for possible errors in the analytical procedures. The level of error in the data was calculated using the following formula (Appelo and Postma 1996):

Error of ion balance $=\frac{\sum \text { cations }-\sum \text { anions }}{\sum \text { cations }+\sum \text { anions }} \times 100$

An error of up to $\pm 3 \%$ is tolerable, while every water sample with a calculated error outside this range should be measured again. Approximately $95 \%$ of the measured water samples were within this range. This means that the resultant data quality is sufficient for chemical modeling and/or for drawing simple conclusions about water quality.

\section{Data analyses}

A classical statistics, with mean, variance and coefficient of variation (CV), range etc., were computed for each soil properties with the assumption that the data are spatially independent. Finally, descriptive statistics (range, median, $\mathrm{SD}, \max , \min$, etc....) were calculated using Manugistic Inc. (2000). Also a geostatistical software (GS+ 9.1, 2005) was used to construct semivariograms and spatial structure analysis for the data. The theory of geostatistics and its application in soil science has been described in details by Trangmar et al. (1985) and Webster and Oliver (2001). A semivariogram display the change in the semivariance between soil samples as the distance between them increases. The semivariance function $\gamma(\mathrm{h})$ at a given lag (h) is estimated using the following equation (Trangmar et al. 1985):

$\gamma(h)=\frac{1}{2 N(k)} \sum_{i=1}^{N(h)}\left[z\left(x_{i}\right)-z\left(x_{i}+h\right)\right]^{2}$

where: $\gamma(h)=$ semi variance, $Z=$ regionalized variable (i.e. soil property), $Z\left(x_{i}\right)=$ measured sample at point $x_{i}$, $Z \quad\left(x_{i}+h\right)=$ measured sample at point $\left(x_{i}+h\right)$, $N(h)=$ number of pairs separated by distance or lag $h$. 
The kriging estimate can be expressed as:

$Z\left(X_{o}\right)=\sum_{i=1}^{n} \lambda_{i} Z\left(X_{i}\right)$

where: $Z\left(X_{o}\right)=$ estimate of unknown true value, $\lambda_{i}=$ weighted coefficient, $n=$ number of neighboring observation used in kriging.

The kriged values were then used to produce maps for each groundwater properties.

\section{Hydrochemical characteristics}

The hydrochemical characterizations of the groundwater samples were evaluated by using the Piper (Piper 1944) and Gibbs (Gibbs 1970) diagrams. In addition, salinity hazard, sodium adsorption ratio (SAR), Kelly's ratio (KR), residual sodium carbonate (RSC), and magnesium hazard $(\mathrm{MH})$ were calculated to investigate the groundwater suitability for irrigation uses.

- The sodium adsorption ratio is computed as:

$\mathrm{SAR}=\frac{\mathrm{Na}}{\sqrt{\frac{\mathrm{Ca}+\mathrm{Mg}}{2}}}$

where the ionic concentration is in meq $\mathrm{L}^{-1}$.

- The Kelly's ratio is computed as:

$\mathrm{KR}=\frac{\mathrm{Na}}{\mathrm{Ca}+\mathrm{Mg}}$

where the ionic concentrations are in meq $\mathrm{L}^{-1}$.

- Residual Sodium Carbonate (RSC) is as:

$\mathrm{RSC}=\left(\mathrm{CO}_{3}^{-}+\mathrm{HCO}_{3}^{-}\right)-\left(\mathrm{Ca}^{2+}+\mathrm{Mg}^{2+}\right)$

where the ions are expressed in meq $\mathrm{L}^{-1}$.

- Magnesium Hazard (MH) was calculated on the basis of the following equation (Szabolcs and Darab, 1964):

$\mathrm{MH}=\frac{\mathrm{Mg}}{\mathrm{Ca}+\mathrm{Mg}} \times 100$

where the ions are expressed in meq $\mathrm{L}^{-1}$.

\section{Results and discussion}

\section{Hydro-geochemistry of groundwater}

The chemical data of the groundwater samples were plotted on a Piper trilinear (Piper 1944) diagram (Fig. 2). The piper diagrams provide a convenient method to classify water types collected from different groundwater resources, based on the ionic composition of different water samples (Al-Omran et al. 2012). The piper diagram reveals that the majority of Al-Kharj groundwater is calciummagnesium/sulfate-chloride water types. It also may be seen that there is a predominance of sodium and magnesium/calcium which influences the tendencies towards the chloride/sulfate-sodium/magnesium and calcium facies (Al-Omran et al. 2016).

Gibbs's diagrams, representing the ratios of $\mathrm{Na}^{+}+\mathrm{K}^{+}$: $\left(\mathrm{Na}^{+}+\mathrm{Ca}^{2+}+\mathrm{Mg}^{2+}\right)$ and $\left.\mathrm{Cl}^{-}:\left(\mathrm{Cl}^{-}\right)+\mathrm{HCO}_{3}{ }^{-}\right)$as a function of TDS, are widely employed to assess the functional sources of dissolved chemical constituents, such as precipitation-dominance, rock-dominance and evaporationdominance (Gibbs 1970). The Chemical data of groundwater sample points of the studied area are plotted in Gibbs's diagrams (Fig. 3). The distribution of sample points suggests that the chemical weathering of rockforming minerals and evaporation are influencing the groundwater quality. Evaporation increases salinity by increasing $\mathrm{Na}^{+}$and $\mathrm{Cl}^{-}$with relation to increase of TDS. The rock domain suggests that rock-water interaction is the major source of dissolved ions over the control of groundwater chemistry. The rock-water interaction process includes the chemical weathering of rocks, dissolutionprecipitation of secondary carbonates and ion exchange between water and clay minerals. The evaporation greatly increases the concentrations of ions formed by chemical weathering, leading to higher salinity. The moving of groundwater sampling points in the Gibbs field towards the evaporation domain from the rock domain suggests an increase of $\mathrm{Na}^{+}$and $\mathrm{Cl}^{-}$ions and consequent higher TDS due to water contamination, caused by the influences of poor sanitary conditions, agricultural fertilizers, and irrigation-return flows (Kumar et al. 2014).

\section{Interpolation using geostatistical software}

A Geostatistical software (GS+9.1) was used to construct semivariograms and spatial structure analysis for the studied groundwater data. The $\mathrm{EC}$ and $\mathrm{NO}_{3}{ }^{-}$frequency and their spherical isotropic semivariograms are shown in Figs. 4, 5 and 6. The Variance ratio, structural variance as related to sill, and $r^{2}$ are presented in Table 2 . The results indicated that $57.353 \%$ of EC variations are due to structural variance of spatial variability of the EC and the random variance accounted to 42.647 . However, $98.309 \%$ of $\mathrm{NO}_{3}{ }^{-}$variations are due to structural variance of spatial variability of the $\mathrm{NO}_{3}{ }^{-}$, while the random variance was only 1.691 . The spherical model was the best variogram to fit the present data. The variogram model is useful in predicting the values of the groundwater parameter for unsampled locations. The results showed that the effective range was 0.08 and $51.10 \mathrm{~m}$ for $\mathrm{EC}$ and $\mathrm{NO}_{3}{ }^{-}$, respectively. This mean that the least distance of groundwater EC and $\mathrm{NO}_{3}{ }^{-}$sampling are 0.8 and $51.10 \mathrm{~m}$, respectively 
Fig. 2 Piper diagram

Piper Diagram
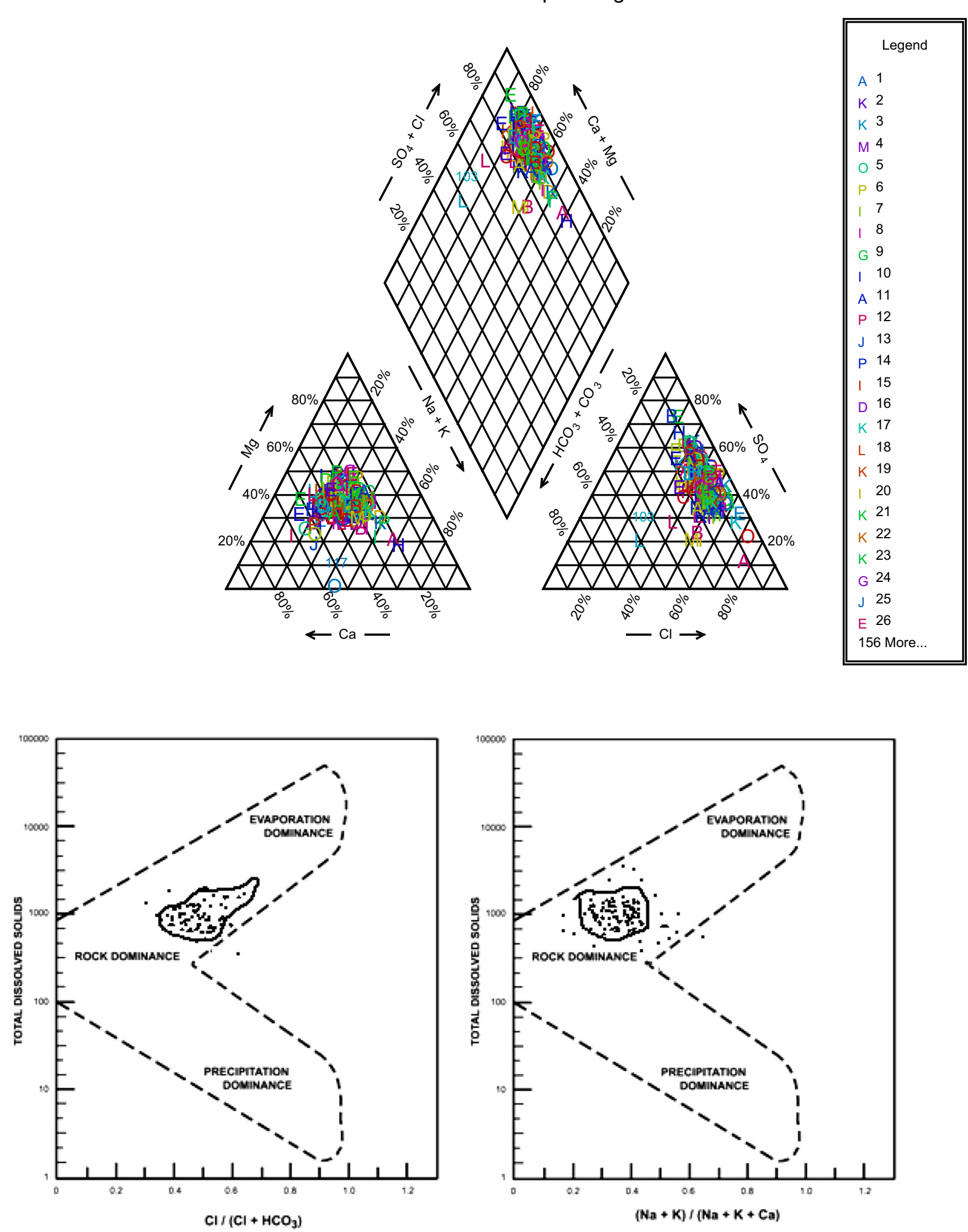

Fig. 3 Diagram depicting the mechanism controlling groundwater quality 
Fig. 4 EC and $\mathrm{NO}_{3}{ }^{-}$frequency

NonTransformed
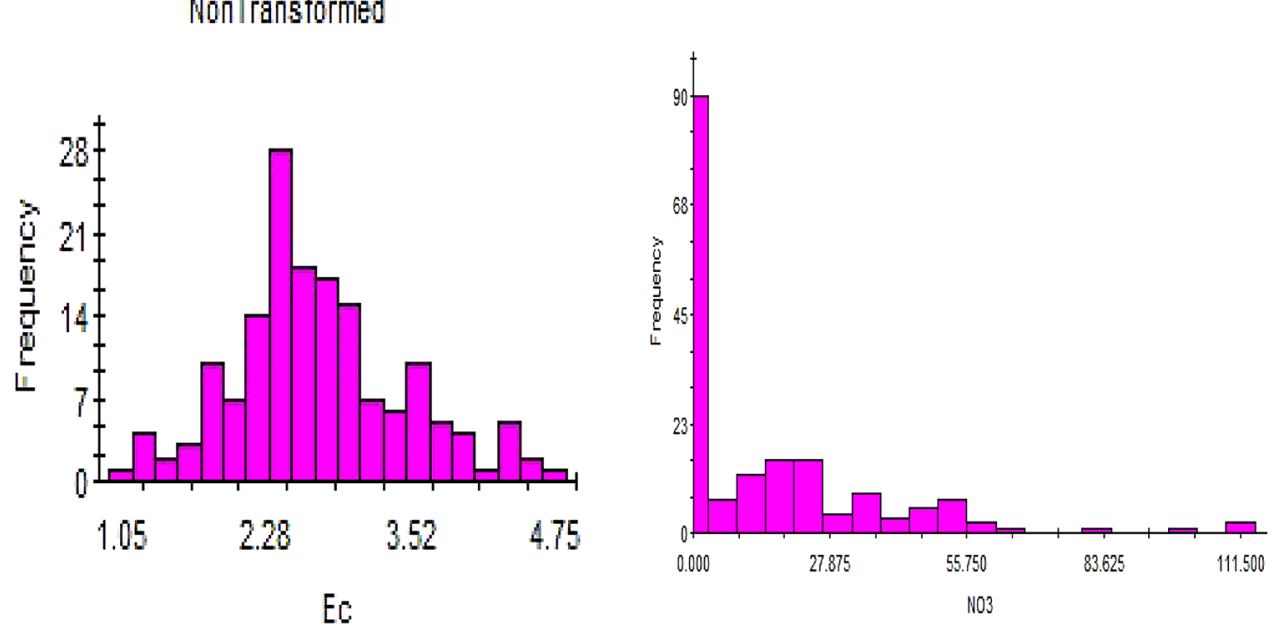

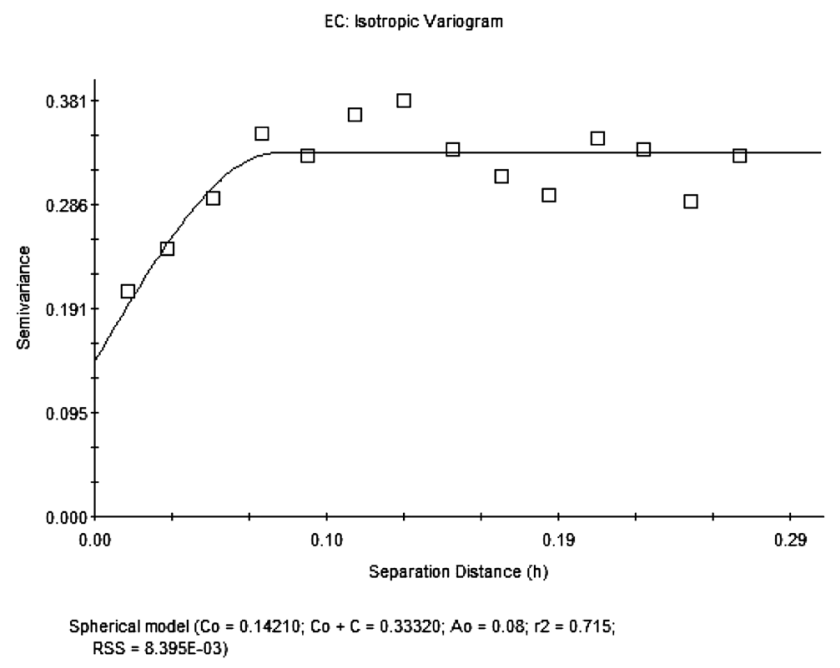

Fig. 5 Isotropic semivariograms of groundwater EC of 180 points

NO3: Isotropic Variogram

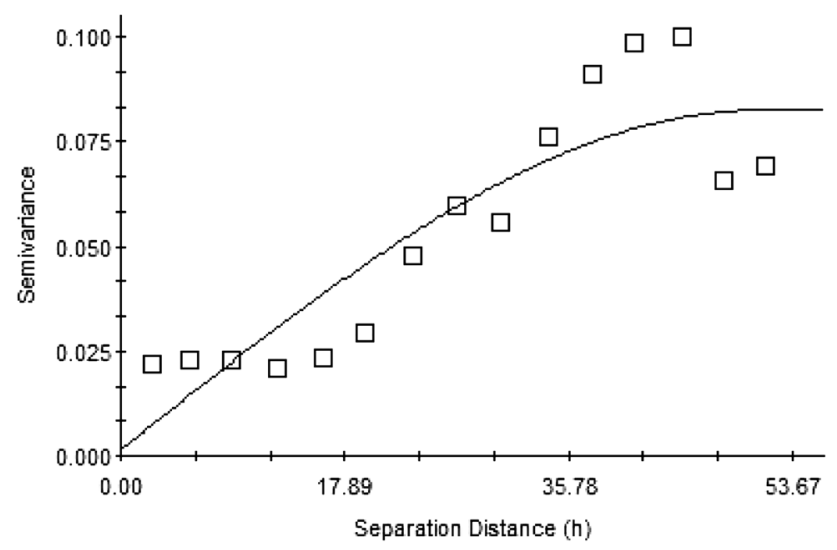

Fig. 6 Isotropic semivariograms of groundwater $\mathrm{NO}_{3}$ of 180 points
(Table 2), due to homogeneity within these distance (Utset and Castellanos 1999).

\section{Comparing interpolation using GS+ and GIS}

In this study, the coordinates of the groundwater samples were recorded by GPS with an accuracy of $\sim 5 \mathrm{~m}$. The GPS signal is corrected by a radio signal in real time. The locations of the groundwater salinity were configured as a comma-delimited text file (in the form of groundwater no, easting, and northing). The point data was overlaid on a satellite image by Arc GIS 9.3 software (ESRI 2010). The kriging interpolation using geostatistical method for EC was carried out using kriging interpolation tool of geostatistical analyst of ArcGIS 9.3 and geostatistical software of GS+ 9.1. Figures 7,8 and 9 concluded that the groundwater in western part of studied ecosystem is considered highly saline since its salinity almost more than 4.75 and $6 \mathrm{dS} \mathrm{m}^{-1}$ for interpolation using GS+ and ArcGIS, respectively. Furthermore, both interpolation methods illustrate that the eastern part of AlKharj contains groundwater of higher quality than western part since its EC around $2 \mathrm{dS} \mathrm{m}^{-1}$. These finding is in agreement with the finding of Aly et al. (2016). This study suggest that using the interpolation methods of geostatistical software (GS+ 9.1) and ArcGIS 9.3 are efficient in groundwater quality prediction of unsampled sites and give almost same results $\left(R^{2}=94 \%\right)$ (Foroughifara et al. 2013; Delbari et al. 2013).

\section{Water quality evaluation for drinking and domestic purposes}

The statistical analysis of the Al-Kharj groundwater was carried out to identify the suitability of the water for drinking purposes using the standard of WHO (2011) (Table 1). It was recorded that the mean, median, and 


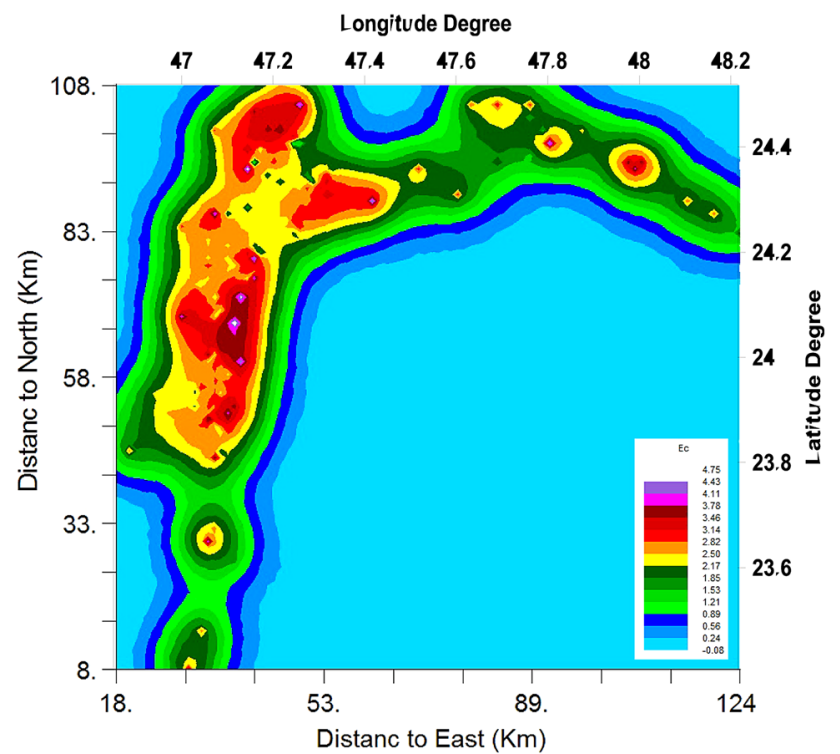

Fig. 7 Interpolation of groundwater EC using GS+

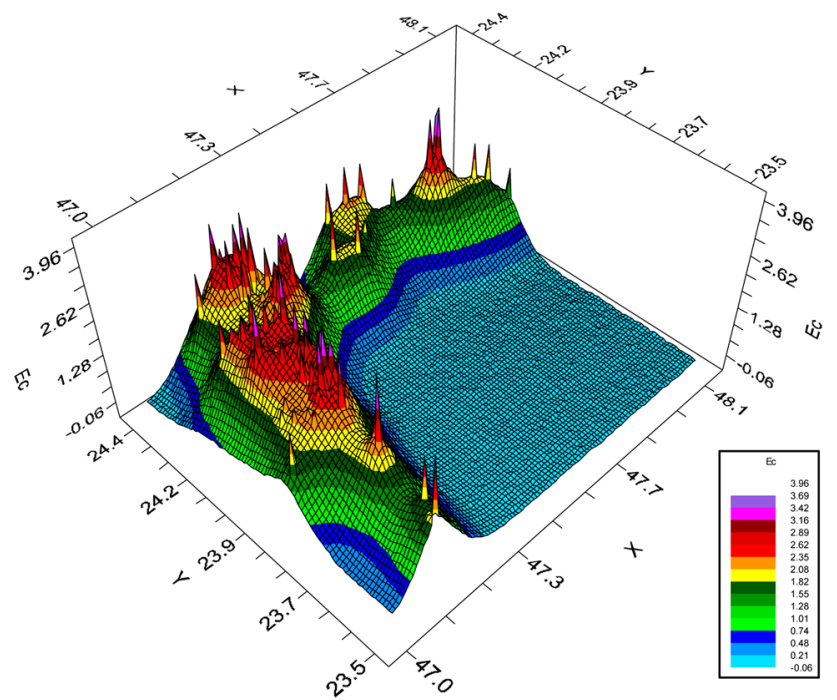

Fig. 8 EC $\left(\mathrm{dS} \mathrm{m}^{-1}\right)$ simulated 3D Map (distance $(\mathrm{km})$ and coordinates $\left(^{\circ}\right)$ ) using GS+

maximum values of the $\mathrm{EC}, \mathrm{Cl}^{-}$, and $\mathrm{SO}_{4}{ }^{-}$exceeded the acceptable limits of the used standard (Al-Omran et al. 2016) (Table 1, Fig. 2). Furthermore, 8 and $61 \%$ of studied water samples were exceeded the permissible limits for $\mathrm{NO}_{3}{ }^{-}$and $\mathrm{B}$, respectively (Table 1 ). The main reason of high $\mathrm{NO}_{3}{ }^{-}$concentrations in some groundwaters is the over application of fertilizer on surrounding agricultural land (Al-hadithi 2012; Aly et al. 2015b).

\section{Water quality evaluation}

The statistical analysis revealed that the groundwater samples $\mathrm{pH}$ ranged between 6.78 and 8.6 with an average of 7.72 (Table 1). This means that the waters were suitable for irrigation with respect $\mathrm{pH}$. On the other hand, the waters salinity (EC) ranged between 1.05 and $10.15 \mathrm{dS} \mathrm{m}^{-1}$ with an average of $3.00 \mathrm{dS} \mathrm{m}^{-1}$ (Table 1, Fig. 4). This illustrate that this waters can be used for irrigation of high salinity tolerance crops (Ayers and Westcot 1985). The excessive sodium content in water sample reduces the permeability, and hence, the available water for the plant is reduced. Sodium replacing adsorbed calcium and magnesium is a hazard, as it causes damage to the soil structure resulting in compact and impervious soil (Arveti et al. 2011). Excess absorption of sodium can cause sodium toxicity in sensitive plants, causing marginal leaf burn on older foliage and possibly defoliation and water containing excessive amount of sodium may immobilize other nutrient ions particularly calcium, magnesium and potassium, which can result in deficiencies of these elements in plants (Sharifi and Safari Sinegani 2012). One of the most important criteria in determining sodium hazard is sodium adsorption ratio (SAR) (Todd and Mays 2005). The SAR values of the groundwater samples varied from 1.08 to 9.14 with an average value of 3.74. All SAR values of the water samples were less than 10 and are classified as excellent for irrigation (Richards 1954). Kelly (1940) has also determined the hazardous effect of sodium on water quality for irrigation usage in terms of Kelly's ratio (KR). A Kelly's ratio of more than one indicates excessive sodium in water. Therefore, water with a Kelly's ratio less than one is considered suitable for irrigation; on the other hand, the ratios more than one are unsuitable. The Kelly's ratios of studied waters were ranged between 0.2 and 2.3 with an average value of 0.7 (Table 1). About $93.3 \%$ of the studied waters were considered suitable for irrigation since Kelly's ratio less than one (Ayers and Westcot 1985). The USSL diagram (Richards 1954) described three salinity classes for $\mathrm{Al}-$ Kharj groundwater (Fig. 10). $40 \%$ of studied waters fall in $\mathrm{C} 3-\mathrm{S} 1,42 \%$ in $\mathrm{C} 4-\mathrm{S} 1$, and the remaining in $\mathrm{C} 4-\mathrm{S} 2$ representing high to very high salinity hazards with low to medium sodium hazards, respectively (Fig. 10). The high salinity is considered a main problems when using groundwater for irrigation in study area. These waters cannot be used for irrigation of sensitive crops for salinity; however, can be used for salinity tolerant crops (Aly et al. 2016) (Table 2).

Residual sodium carbonate (RSC) is also calculated in this study. A negative RSC means that sodium buildup is unlikely since sufficient calcium and magnesium are in excess of what can be precipitated as carbonates. A positive RSC indicates that sodium buildup in the soil is possible. The zero RSC means no sodium hazard anticipated; however, RSC $=0-1.25,1.25-2.50$, and $>2.50$ mean low, 


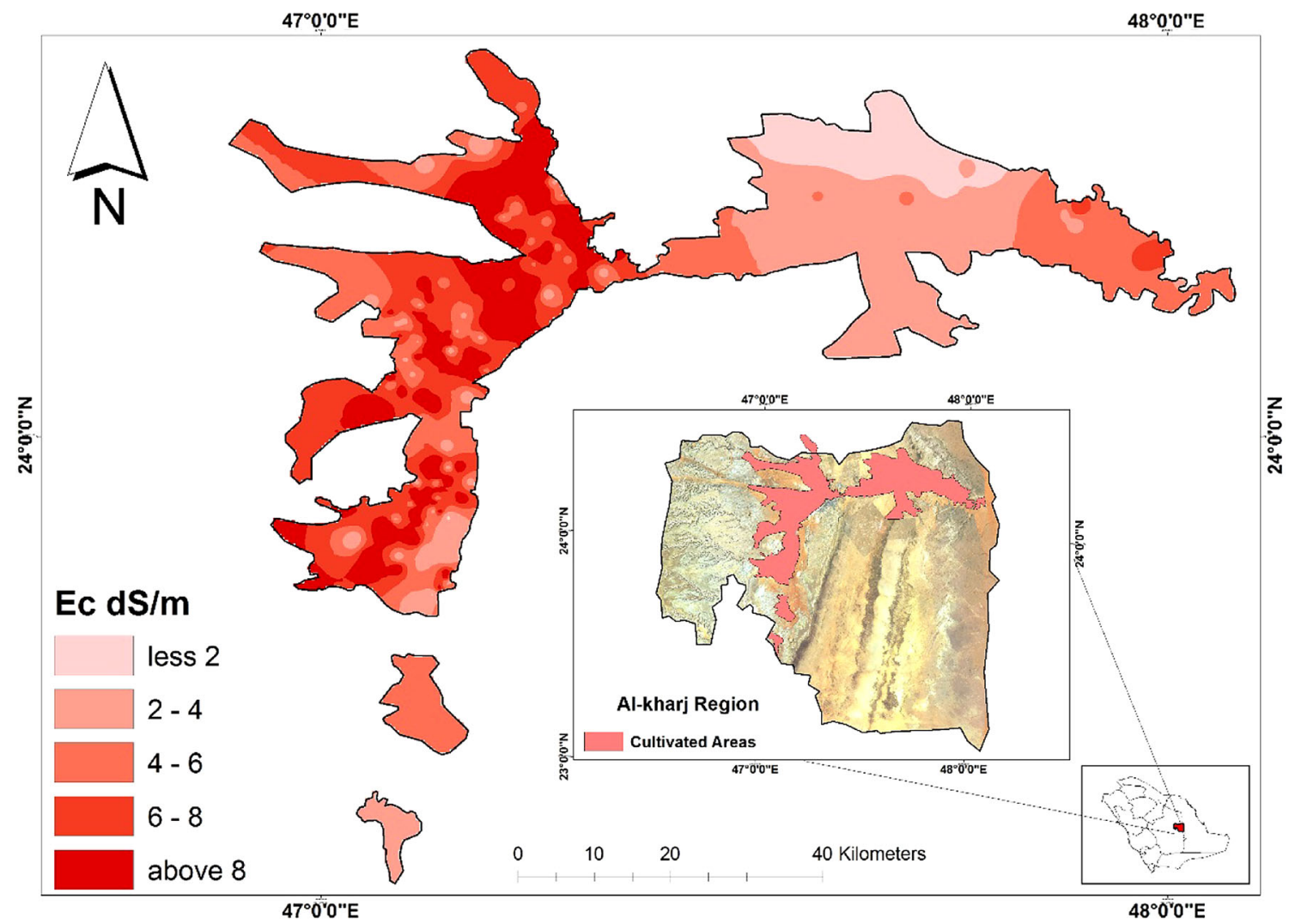

Fig. 9 Interpolation of groundwater EC using Arc-GIS

Table 1 Descriptive statistics of Al-Kharj groundwater chemical composition ( $n=180)$

\begin{tabular}{|c|c|c|c|c|c|c|c|c|c|c|c|c|c|c|c|c|}
\hline & PH & $\begin{array}{l}\mathrm{EC} \\
\mathrm{dS} \mathrm{m^{-1 }}\end{array}$ & $\begin{array}{l}\mathrm{Ca}^{2+} \\
\text { meq } \mathrm{L}\end{array}$ & $\mathrm{Mg}^{2+}$ & $\mathrm{Na}^{+}$ & $\mathrm{K}^{+}$ & $\mathrm{Cl}^{-}$ & $\mathrm{HCO}_{3}^{-}$ & $\mathrm{CO}_{3}^{-2}$ & $\mathrm{SO}_{4}^{-2}$ & SAR & $\begin{array}{l}\text { B } \\
\text { mg L }\end{array}$ & ${ }_{-1}^{\mathrm{NO}_{3}}$ & $\mathrm{KR}$ & RSC & MH \\
\hline Max. & 8.60 & 10.15 & 36.75 & 29.85 & 43.40 & 0.72 & 58.17 & 18.83 & 4.33 & 43.19 & 9.14 & 3.06 & 111.50 & 2.27 & -3.5 & 61.9 \\
\hline Mini. & 6.78 & 1.05 & 3.45 & 0.79 & 2.24 & 0.05 & 3.13 & 0.87 & 0.00 & 3.22 & 1.08 & 0.02 & 0.00 & 0.18 & -64.0 & 3.2 \\
\hline Mean & 7.72 & 3.00 & 10.79 & 7.78 & 11.28 & 0.25 & 10.86 & 3.99 & 0.13 & 15.03 & 3.74 & 0.63 & 14.67 & 0.65 & -14.5 & 42.2 \\
\hline Stdev & 0.44 & 1.29 & 5.09 & 3.93 & 5.96 & 0.10 & 7.32 & 1.49 & 0.37 & 7.05 & 1.47 & 0.43 & 21.22 & 0.30 & 8.5 & 8.2 \\
\hline Vari. & 0.66 & 1.13 & 2.26 & 1.98 & 2.44 & 0.31 & 2.71 & 1.22 & 0.61 & 2.66 & 1.21 & 0.66 & 4.61 & 0.55 & 2.9 & 2.9 \\
\hline St. error & 0.18 & 0.23 & 0.33 & 0.31 & 0.34 & 0.12 & 0.36 & 0.24 & 0.17 & 0.36 & 0.24 & 0.18 & 0.47 & 0.16 & 0.13 & 0.13 \\
\hline Med. & 7.72 & 2.64 & 9.60 & 6.69 & 10.21 & 0.23 & 9.50 & 3.83 & 0.00 & 12.83 & 3.51 & 0.60 & 2.05 & 0.58 & -12.61 & 42.01 \\
\hline Skew & -0.15 & 2.47 & 1.39 & 2.16 & 2.53 & 1.66 & 3.85 & 5.96 & 8.20 & 1.18 & 1.12 & 1.84 & 2.08 & 1.90 & -1.84 & -0.65 \\
\hline $\begin{array}{l}\text { WHO drinking water } \\
\text { standard }\end{array}$ & $6.5-8.5$ & 0.94 & - & - & - & - & 7.0 & - & - & 8.3 & - & 0.5 & 50.0 & - & - & - \\
\hline
\end{tabular}

medium and high sodium hazardous, respectively. All studied water samples RSC below zero which mean that there is no hazardous of sodium due to using these type of water (Table 1) (Eaton 1950).

Magnesium Hazard (MH) was calculated on the basis of Eq. (7). Magnesium present in water would adversely affect the soil quality (Venugopal et al. 2009). If magnesium hazard was less than 50, the water can considered safe and suitable for irrigation (Szabolcs and Darab 1964). 86\% of studied water samples had $\mathrm{MH}<50$, it suitable for irrigation. However, remaining samples had MH ranged between 51 and 62 (Table 1). No harmful effect of these waters due to 


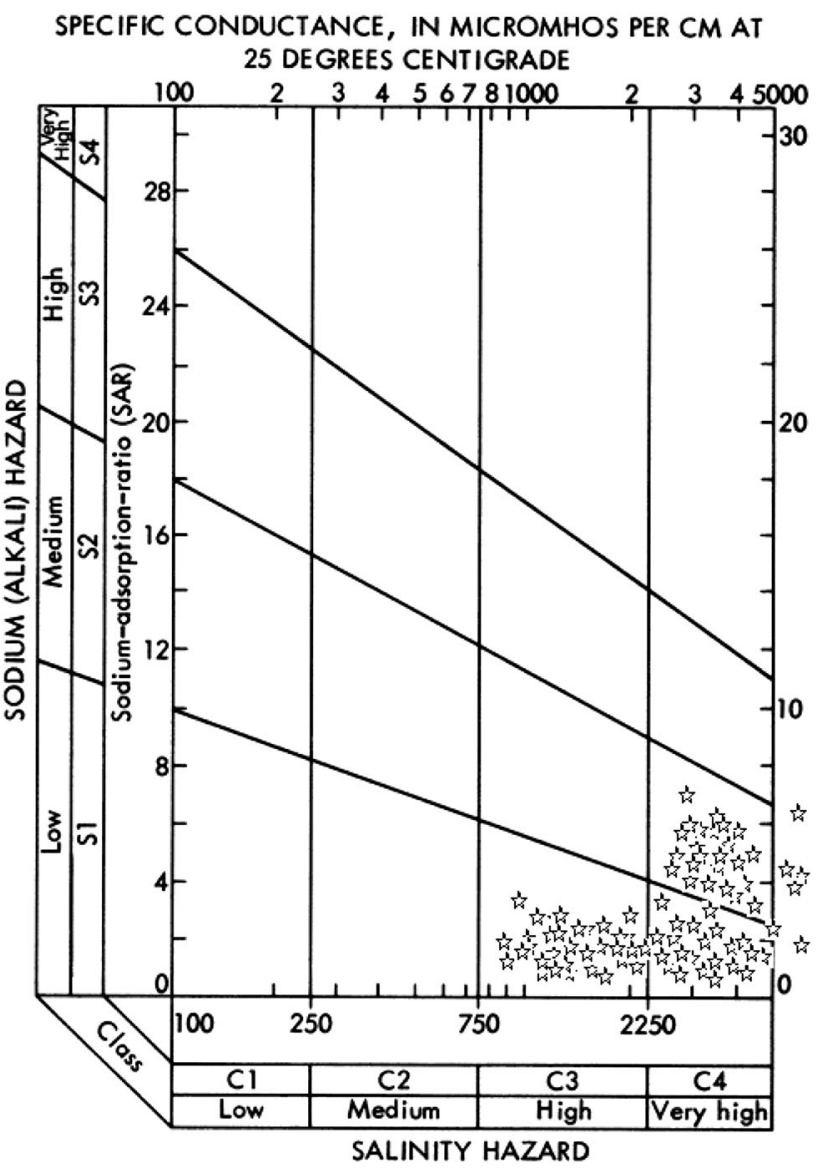

Fig. 10 Salinity classification of Al-Kharj groundwater

boron toxicity with exception $11.1 \%$ of studied water sam-

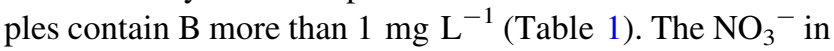
studied area ranged between 0.00 and $111.5 \mathrm{mg} \mathrm{L}^{-1}$ with an average of $14.7 \mathrm{mg} \mathrm{L}^{-1}$. The $\mathrm{NO}_{3}^{-}$concentrations increased dramatically to reach $111 \mathrm{mg} \mathrm{L}^{-1}$ in two sites due to the use of $\mathrm{NO}_{3}{ }^{-}$fertilizers in these agriculture area (Tiwari and Singh 2014) (Table 1, Fig. 4).

\section{Conclusion}

The Al-Kharj groundwaters chemical analysis revealed that the waters salinity (EC) ranged between 1.05 and $10.15 \mathrm{dS} \mathrm{m}^{-1}$ with an average of $3.00 \mathrm{dS} \mathrm{m}^{-1}$. This illustrate that this waters are unsuitable for drinking; however, they can be used only for irrigation of high salinity tolerant crops. Some groundwater found contaminated with nitrate; yet, no harmful effect with respect to boron toxicity when use these waters for irrigation. The SAR, Kelly's ratio, RSC, and MH concluded that there are no sodium or magnesium hazard are anticipated. The USSL (1954) diagram described three salinity classes; C3-S1, C4-S1, and C4-S2 representing high to very high salinity hazards with low to medium sodium hazards, respectively. The high salinity is considered main problems when use these groundwaters for irrigation. The main reasons of the groundwaters deterioration in the study area are the overexploitation of groundwater by large agriculture investment companies and the intensive use of nitrogen fertilizers. Many sane use of saline irrigation water are currently in use, including cyclic strategy (saline and non-saline water in a repeating sequence), blending strategy (dilution process), rotation strategy (low-salinity water for salt sensitive crops in a rotation with saline water for salttolerant crops), and planting salt tolerant crop varieties or genotypes/cultivars. Kriging can be considered as an appropriate technique for illustrating the distribution of $\mathrm{EC}$ and $\mathrm{NO}_{3}{ }^{-}$in groundwaters. The Kriged maps can facilitate the better groundwater management. Preparation of such kinds of maps before setting up strategies could be helpful in devising ways for making sustainable ecosystem management. Kriging interpolation of the groundwater's EC using geostatistical analyst of ArcGIS 9.3 and geostatistical software $(\mathrm{GS}+9.1)$ concluded that the groundwater in western part of AlKharj is considered highly saline since its salinity almost more than 4.75 and $6.00 \mathrm{dS} \mathrm{m}^{-1}$ when make interpolation using GS+ and ArcGIS, respectively. Furthermore, both interpolation methods illustrate that the eastern part of AlKharj contains groundwater of higher quality than western area. This study recommend that using the interpolation methods of geostatistical software (GS+ 9.1) and ArcGIS 9.3 are efficient in groundwater quality prediction of un-sampled sites and give almost same results $\left(R^{2}=94 \%\right)$.

Table 2 Isotropic semivariance analysis of $\mathrm{NO}_{3}$ at 180 sites

\begin{tabular}{llllllrr}
\hline Groundwater parameter & Best model & $\begin{array}{l}\text { Nugget variance } \\
\left(C_{\mathrm{o}}\right)\end{array}$ & $\begin{array}{l}\text { Structural } \\
\text { variance }(C)\end{array}$ & Sill $C_{\mathrm{o}}+C$ & $\begin{array}{l}\text { Variance ratio } \\
C / C_{\mathrm{o}}+C\end{array}$ & $\begin{array}{l}\text { Effective } \\
\text { range } A_{\mathrm{o}}(\mathrm{m})\end{array}$ \\
\hline $\left.\mathrm{EC}(\mathrm{dS} \mathrm{m})^{-1}\right)$ & Spherical & 0.14210 & 0.1911 & 0.33320 & 0.57353 & 0.08 \\
$\mathrm{NO}_{3}\left(\mathrm{mg} \mathrm{L}^{-1}\right)$ & Spherical & 0.00140 & 0.0814 & 0.08280 & 98.309 & 51.10 \\
\hline
\end{tabular}


Acknowledgements This project was supported by NSTIP Strategic Technologies Program Number (12-ENV2581-02) in the Kingdom of Saudi Arabia.

Open Access This article is distributed under the terms of the Creative Commons Attribution 4.0 International License (http:// creativecommons.org/licenses/by/4.0/), which permits unrestricted use, distribution, and reproduction in any medium, provided you give appropriate credit to the original author(s) and the source, provide a link to the Creative Commons license, and indicate if changes were made.

\section{References}

Adhikary PP, Dash ChJ, Chandrasekharan H, Rajput TBS, Dubey SK (2012) Evaluation of groundwater quality for irrigation and drinking, using GIS and geostatistics in a peri-urban area of Delhi, India. Arab J Geosci 5:1423-1434

Al-hadithi M (2012) Application of water quality index to assess suitability of groundwater quality for drinking purposes in Ratmao-Pathri Rao watershed, Haridwar District, India. Am J Sci Ind Res 3(6):395-402. doi:10.5251/ajsir.2012.3.6.395.402

Al-Omran AM, Abdel-Nasser G, Choudhar I, Al-Otuibi J (2004) Spatial variability of soil $\mathrm{pH}$ and salinity under date palm cultivation. Res Bult No (128) Agric Res Center, King Saud Univ pp 5-36

Al-Omran MA, El-Maghraby SE, Aly AA, Al-Wabel IM, Al-Asmari ZA, Nadeem ME (2012) Quality assessment of various bottled waters marketed in Saudi Arabia. Environ Monit Assess 185(8):6397-6406

Al-Omran AM, Aly AA, Al-Wabel MI, Sallam AS, Al-Shayaa MS (2016) Hydrochemical characterization of groundwater under agricultural land in arid environment: a case study of Al-Kharj, Saudi Arabia. Arab J Geosci 9:68-85. doi:10.1007/s12517-0152136-5

Aly A, Al-Omran AM, Khasha A (2015a) Water management for cucumber: greenhouse experiment in Saudi Arabia and modeling study using SALTMED model. J Soil Water Conserv 70(1):1-11. doi:10.2489/jswc.70.1.1

Aly AA, Al-Omran AM, Alharby MM (2015b) The water quality index and hydrochemical characterization of groundwater resources in Hafar Albatin, Saudi Arabia. Arab J Geosci 8(6):4177-4190. doi:10.1007/s12517-014-1463-2

Aly AA, Al-Omran AM, Sallam AS, Al-Wabel MI, Al-Shayaa MS (2016) Vegetation cover change detection and assessment in arid environment using multi-temporal remote sensing images and ecosystem management approach. Solid Earth 7:713-725. doi:10.5194/se-7-713-2016

APHA (1998) Standard methods for the examination of water and waste water, 20th edn. American Public Health Association, Washington DC

Appelo CAJ, Postma D (1996) Geochemistry, groundwater and pollution. A.A., Balkema, Rotterdam

Arveti N, Sarma MRS, Aitkenhead-Peterson JA, Sunil K (2011) Fluoride incidence in groundwater: a case study from Talupula, Andhra Pradesh, India. Environ Monit Asses 172:427-443

Ayers RS, Westcot DW (1985) Water quality for agriculture irrigation and drainage paper 29 (rev.1). FAO, Rome, Italy

Bingham FT (1982) Boron. In: Page AL, Miller RH, Keeney DR (eds) Methods of soil analysis, part 2, Madison, WI: Agronomy Society of America, Soil Science Society of America, pp 431-47

Burgess TM, Webster R, McBratney AB (1981) Optimal interpolation and isarithmic mapping of soil properties. IV. Sampling strategy. J Soil Sci 31:642-659
Cemek B, Guler M, Kilic K, Demuir Y, Arslan H (2007) Assessment of spatial variability in some soil properties as related to soil salinity and alkalinity in Bafra plain in northern Turkey. Environ Monit Asses 124:223-234

Delbari M, Motlagh BM, Kiani M, Amiri M (2013) Investigating spatio-temporal variability of groundwater quality parameters using geostatistics and GIS. IRJABS 4(10):3623-3632

Eaton FM (1950) Significance of carbonates in irrigation waters. Soil Sci 69:123-133

El-Sayed MH, Abo El-Fadl MM, Shawky HA (2012) Impact of hydrochemical processes on groundwater quality, Wadi Feiran, South Sinai, Egypt. Aust J Basic Appl Sci 6(3):638-654

ESRI (2010) Arc View version 10 user manual. Redlands, CA, USA

Foroughifara H, Jafarzadeha AA, Torabib H, Pakpoura A, Miransaric M (2013) Using geostatistics and geographic information system techniques to characterize spatial variability of soil properties, including micronutrients. Commun Soil Sci Plant Anal 44:1273-1281

Gibbs RJ (1970) Mechanisms controlling world water chemistry. Science 17:1088-1090

Goovaerts P (1992) Factorial krigging analysis: a useful tool for exploring the structure of multivariate spatial information. J Soil Sci 43:597-616. doi:10.1111/j.1365-389.1992.tb00163.x

Goovaerts P (1998) Geostatistical tools for characterizing the spatial variability of microbiological and physico-chemical soil properties. Biol Fertil Soils 27:315-334. doi:10.1007/s003740050439

Imrie CE, Korre A, Munoz-Melendez G, Thornton I, Durucan S (2008) Application of factorial krigging analysis to the Foregs European topsoil geochemistry database. Sci Total Environ 393:96-110. doi:10.1016/j.scitotenv.2007.12.012

Kelly WP (1940) Permissible composition and concentration of irrigated waters. In: Proceedings of the A.S.C.F, 607

Khashei-Siuki A, Sarbazi M (2015) Evaluation of ANFIS, ANN, and geostatistical models to spatial distribution of groundwater quality (case study: Mashhad plain in Iran). Arab J Geosci 8(2):903-912

Kumar V, Remadevi (2006) Kriging of groundwater level a case study. JOSH 6(1):81-91

Kumar KS, Bharani R, Magesh NS, Godson PS, Chandrasekar N (2014) Hydrogeochemistry and groundwater quality appraisal of part of south Chennai coastal aquifers, Tamil Nadu, India using WQI and fuzzy logic method. Appl Water Sci 4(4):341-350. doi:10.1007/s13201-013-0148-4

Ledesma-Ruiz R, Pastén-Zapata E, Parra R, Harter T, Mahlknecht J (2015) Investigation of the geochemical evolution of groundwater under agricultural land: a case study in northeastern Mexico. J Hydrol 521:410-423. doi:10.1016/j.jhydrol.2014.12. 026

Mahato MK, Singh PK, Tiwari AK (2016) Hydrogeochemical evaluation of groundwater quality and seasonal variation in East Bokaro Coalfield Region, Jharkhand. J Geol Soc India 88:173-184. doi:10.1007/s12594-016-0476-8

Manugistics, STATGRAPHIC plus 2000. User manual Maryland, Manugistics Inc

Marko K, Al-Amri NS, Elfeki AMM (2013) Geostatistical analysis using GIS for mapping groundwater quality: case study in the recharge area of Wadi Usfan, western Saudi Arabia. Arab J Geosci 7(12):5239-5252. doi:10.1007/s12517-013-1156-2

Matiti SK (2004) Handbook of methods in environmental studies: water and wastewater analysis. ABD Publishers, Jaipur (India)

McBratney AB, Webster R (1983) Optimal interpolation and isarithm mapping of soil properties. V: Co regionalization and multiple sampling strategies. Eur J Soil Sci 34:137-162

Narany TS, Ramli MF, Aris AZ, Sulaiman WA, Fakharian K (2015) Groundwater irrigation quality mapping using geostatistical techniques in Amol-Babol Plain, Iran. Arab J Geosci 8:961-976 
Nas B (2009) Geostatistical approach to assessment of spatial distribution of groundwater quality. Pol $\mathrm{J}$ Environ Stud 18:1073-1082

Piper AM (1944) A graphic procedure in the geochemical interpretation of water analysis. Trans Am Geophys Union 25:914-928

Richards LA (1954) (Ed) Diagnosis and improvement of saline and alkali soils. USDA Hand book, No. 60, 160

Sharifi Z, Safari Sinegani AA (2012) Arsenic and other irrigation water quality indicators of groundwater in an agricultural area of Qorveh Plain, Kurdistan, Iran. Am Eurasian J Agric Environ Sci 12(4):548-555

Singh AK, Raj B, Tiwari AK, Mahato MK (2013) Evaluation of hydrogeochemical processes and groundwater quality in the Jhansi district of Bundelkhand region, India. Environ earth sci 70(3):1225-1247. doi:10.1007/s12665-012-2209-7

Szabolcs I, Darab C (1964) The influence of irrigation water of high sodium carbonate content of soils. Proc Int Congress Trans 2:803-812

Tabatabai MA (1996) Sulfur, p. 921-960. In: Sparks DL et al (ed) Methods of soil analysis. Part 3. Chemical methods. SSSA Book Ser. 5. ASA and SSSA, Madison, WI

Tiwari AK, Singh AK (2014) Hydrogeochemical investigation and groundwater quality assessment of Pratapgarh district, Uttar Pradesh. J Geol Soc India 83:329-343. doi:10.1007/s12594-0140045-y

Tiwari AK, Singh AK, Singh AK, Singh MP (2015) Hydrogeochemical analysis and evaluation of surface water quality of Pratapgarh district, Uttar Pradesh, India. Appl Water Sci. doi:10.1007/ s13201-015-0313-Z

Tiwari AK, De Maio M, Singh PK, Singh AK (2016a) Hydrogeochemical characterization and groundwater quality assessment in a coal mining area, India. Arab J Geosci 9(3):1-17. doi:10.1007/ s12517-015-2209-5

Tiwari AK, Singh PK, Mahato MK (2016b) Environmental geochemistry and a quality assessment of mine water of the West Bokaro coalfield, India. Mine Water Environ 35(4):525-535. doi:10.1007/s10230-015-0382-0

Todd DK, Mays LW (2005) Groundwater hydrology, 3rd edn. Wiley, Hoboken, NJ, p 656

Trangmar BB, Yost RS, Uehara G (1985) Application of geostatistics to spatial studies of soil properties. Adv Agron 38:45-93

Utset A, Castellanos A (1999) Drainage effects on spatiall variability of soil electrical conductivity in a vertisol. Agric Water Manag 38:213-222

Vaezil AR, Bahrami HA, Sadeghi SHR, Mahdian MH (2010) Spatial variability of soil erodibility factor (K) of the USLE in North West of Iran. J Agric Sci Technol 12:241-252

Venugopal T, Giridharan L, Jayaprakash M, Periakali P (2009) Environmental impact assessment and seasonal variation study of the groundwater in the vicinity of River Adyar, Chennai, India. Environ Monit Assess 149:81-97

Vincent P (2008) Hydrogeology and hydrology. In: Peter V (ed) Saudi Arabia: an environmental overview. Taylor \& Francis/ Balkema, Leiden, pp 105-109

Webster R, Burgess MT (1980) Optimal interpolation and isarithmic mapping of soil properties. III. Changing drift and universal kriging. J Soil Sci 31:505-524

Webster R, Oliver MA (2001) Geostatistics for environmental scientists. Wiley, Chichester

WHO (2011) Guidelines for drinking-water quality, 4th edn. World Health Organization, Geneva 